\title{
Potent In Vitro $\alpha$-Glucosidase and $\beta$-Secretase Inhibition of Amyrin-Type Triterpenoid Isolated from Datura metel Linnaeus (Angel's Trumpet) Fruits
}

\author{
Saud Bawazeer $\mathbb{D}^{1},{ }^{1}$ Abdur Rauf $\mathbb{D},{ }^{2}$ and Sami Bawazeer $\mathbb{D D}^{3}$ \\ ${ }^{1}$ Department of Pharmaceutical Chemistry, Faculty of Pharmacy, Umm Al-Qura University, Makkah, P.O. Box 42, Saudi Arabia \\ ${ }^{2}$ Department of Chemistry, University of Swabi, Swabi-Anbar-, 23430 KPK, Pakistan \\ ${ }^{3}$ Department of Pharmacognosy, Faculty of Pharmacy, Umm Al-Qura University, Makkah, P.O. Box 42, Saudi Arabia
}

Correspondence should be addressed to Saud Bawazeer; ssbawazeer@uqu.edu.sa and Abdur Rauf; mashaljcs@yahoo.com

Received 2 July 2020; Accepted 8 August 2020; Published 25 August 2020

Academic Editor: Oleg S. Matusovsky

Copyright ( 2020 Saud Bawazeer et al. This is an open access article distributed under the Creative Commons Attribution License, which permits unrestricted use, distribution, and reproduction in any medium, provided the original work is properly cited.

\begin{abstract}
This study deals with $\alpha$-glucosidase and $\beta$-secretase inhibitory screening of extract/fractions and isolated daturaolone (1), namely, 3-oxo-6- $\beta$-hydroxy- $\beta$-amyrin (daturaolone) from chloroform fraction of Datura metel L. Among entire fractions, the chloroform soluble fraction showed excellent activity against $\alpha$-glucosidase with \% inhibition 90.8 with $\mathrm{IC}_{50} 160.2 \pm 1.85 \mu \mathrm{g}$ and daturaolone (1) with $98.7 \%$ inhibition with $\mathrm{IC}_{50} 840.4 \pm 1.74 \mu \mathrm{M}$, respectively. Similarly, extract and daturaolone (1) also exhibited significant activity against the $\beta$-secretase enzyme (BACE1) with \% activities 88.27 and 95.19 and with $\mathrm{IC}_{50}$ values $304.21 \pm 2.98 \mu \mathrm{g}$ and $260.70 \pm 1.87 \mu \mathrm{M}$, respectively, as compared to the standard inhibitor (Ans670, Sta671, Val672)-amyloid- $\beta /$ A4 precursor protein 770 fragments $662-675)$ with $\%$ activity 94.21 and $\mathrm{IC}_{50}$ value $289.24 \pm 1.60 \mu \mathrm{M}$. This finding encourages and opens a new window for further detail phytochemical investigation on $D$. metel in order to isolate novel compounds with promising enzyme inhibitory potential.
\end{abstract}

\section{Introduction}

Datura metel belongs to family Solanaceae which grows throughout the year and is normally known as devil's trumpet $[1,2]$. D. metel is nourished in the humid and hot climate. It is found in India, Pakistan, Africa, and South America [3]. Its flower is long and possessing a white color and has a purple color that scented up to 6 inches [4], while the leaves are green in color and bread in shape. D. metel plant length ranges from 10 to $20 \mathrm{~cm}$ and broad from 5 to $18 \mathrm{~cm}$. Its fruits are $4-10 \mathrm{~cm}$ thick and like a spiny capsule. D. metel is a rich source of manufacturing numerous secondary metabolites such as saponins, flavonoids, triterpenoids, alkaloids, steroids, and tannins [4]. The biological potency of D. metel is correlated due to the presence of secondary metabolites. An alkaloid known as scopolamine is a major compound isolated from $D$. metel has been reported for the treatment of different diseases such as bronchitis and asthma [2]. D. metel is also used for the cure of epilepsy, heart disease, fever, diabetes, insanity, diarrhea, and a skin disease $[5,6]$. It is also a key source of producing anolides, which is also used for the treatment of pain and also have hallucinogenic strength [7-9]. Its seeds are used for the treatment of dental pain. It has extensive application in ayurvedic medication such as many classes of compounds isolated from the title plant that is used to treat hair fall and many skin-related infection disease [10]. The plant extracts of $D$. metel has been reported for anti-inflammatory and antimicrobial effects $[11,12]$. Phytochemical D. metel is discovered very slightly; atropine reported from $D$. metel is used to dilate the pupil and it helps in the surgery of eyes [13]. The $\alpha$-glycosidase catalyzed the hydrolysis of glycosidic bonds in glycoconjugates as well as polysaccharides and act an acute role in different biological processes, such as lysosomal catabolism of glycoconjugates, posttranslational changes of cellular glycoproteins, and digestion of carbohydrate $[14,15]$. Particularly, human $\alpha$-glycosidase enzymes in the mucosal brush edge of the small intestine catalyzed the finale step of digestion of disaccharides and starch present in human food. $\alpha$ - 

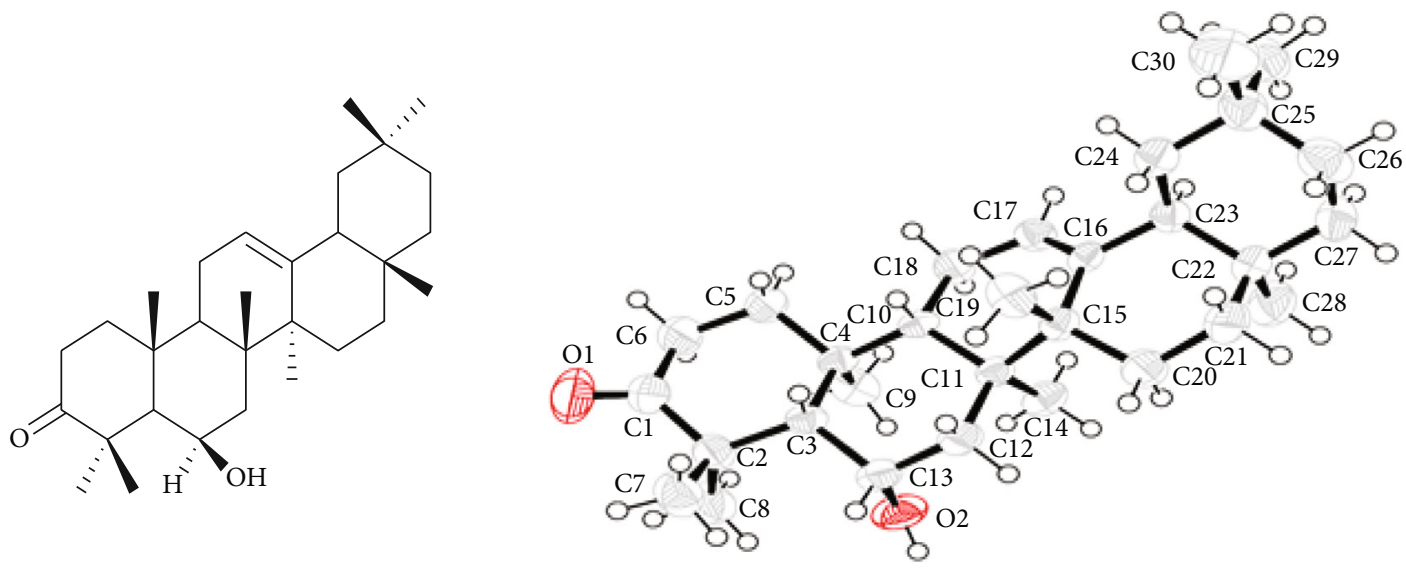

FIgURE 1: Chemical structure and X-ray crystallographic image of daturaolone (1) isolated from D. metel.

Glycosidase in the small intestine is selectively involved in the hydrolysis of terminal $(1 \rightarrow 4)$ connected $\alpha$-glucose residues (disaccharides/starch) to release a single $\alpha$-glucose molecule [14]. Potent $\alpha$-glycosidase inhibitor delay is involved in the reeducation of the postprandial blood glucose excursion and decomposition of carbohydrates in the small intestine; therefore, the inhibitor of $\alpha$-glycosidase has an important effect on metabolism polysaccharide, cellular interaction, glycoprotein processing, and wide chances for the development of new and novel therapeutic agents against various diseases including cancer, viral infection, and metastatic diabetes [15-17]. $\beta$-Secretase is an aspartic proteinase that is involved in numerous functions such as physiological processes in humans, including immunoregulation, death of the cell, and cell differentiation [18]. There are several pieces of evidence that a change in $\beta$-secretase action is involved in various diseases including schizophrenia, epileptic behavior, and Alzheimer's diseases [19]. $\beta$-Secretase enzyme is mainly involved in the breakdown of $\beta$-amyloid precursor protein at one of the two decompositions required to produce $\beta$-amyloid peptides. $\beta$-amyloid peptides are the main compound of amyloid plaques in Alzheimer's disease brain and act as a key role in the pathogenesis of divesting neurodegenerative disorder [18]. The finding deals with the $\alpha$-glucosidase and $\beta$-secretase inhibitory screening of extract/fractions and isolated daturaolone (1), namely, 3 -oxo- 6 - $\beta$-hydroxy- $\beta$-amyrin from chloroform fraction of Datura metel L.

\section{Experimental}

2.1. Plant Material Collection. The plant materials (fruits) of Datura metel were obtained from the hilly area of Razagram Toormang Dara, Dist; Dir, KPK, Pakistan. The plant sample was identified by Dr. Muhammad Ilyas, Head Department of Botany, University of Swabi, KPK, Pakistan. The voucher specimen no. Bot (UOS-521) was placed in the herbarium of the Botany Department of University of Swabi.

2.2. Extractions, Fractionation, and Isolation. The shadedried fruits $(8.2 \mathrm{~kg}$ ) were grinded with the help of a local grinder machine to obtain powder, and then, $8.00 \mathrm{~kg}$ powder plant material was soaked in methanol (40 liters) for 13 days to obtain a crude methanolic extract $350 \mathrm{~g}$. The crude extract was suspended in water $(500 \mathrm{~mL})$ to prepare the paste and then successively extracted with various organic solvent on polarity, to obtain $n$-hexane extract $(50.9 \mathrm{~g})$, chloroform extract $(93.00 \mathrm{~g})$, and ethyl acetate extract $(45.87 \mathrm{~g})$ as per standard methods [20]. A small portion of all obtained extracts was subjected to thin-layer chromatography (TLC), by using different solvent systems; the maximum separation was observed in $n$-hexane and ethyl acetate. Based on the TLC profile, the chloroform fraction was selected for separation because it contains a maximum number of compounds. Among the chloroform extracts, $25.0 \mathrm{~g}$ was chromatographed on silica gel by using normal phase column chromatography. The column was eluted with a mixture of $n$-hexane and ethyl acetate $(0: 100)$ of increasing polarity order. Two hundred fractions were collected, which were combined to 16 major fractions (SB-1-SB16), as per the TLC profile. Based on TLC profile, SB-9 was subjected to repeated pencil column chromatography (CC), eluting with $n$-hexane and ethyl acetate $(14: 86)$, which yielded white crystal. The obtained crystals were washed with $n$-hexane which gives daturaolone (1; 99.89\% pure) $(2.7 \mathrm{~g})$. The chemical structure of daturaolone (1) was elucidated by advanced spectroscopic technique $\left({ }^{1} \mathrm{H}-\mathrm{NMR},{ }^{13} \mathrm{C}-\mathrm{NMR}, \mathrm{HMBC}, \mathrm{HMQC}, \mathrm{NOESY}, \mathrm{COSY}\right.$, and EI-MS). The structure was confirmed by crystallography technique (Figure 1) and compared the spectral data with the reported one $[21,22]$.

\section{Enzyme Inhibitory Screening}

3.1. $\alpha$-Glucosidase Inhibitory Assay. The crude extracts and isolated daturaolone (1) were assessed for $\alpha$-glucosidase inhibitory activity as per reported methods [23, 24]. Rat intestinal $\left(\mathrm{CH}_{3}\right)_{2} \mathrm{CO}$ (acetone) powder in normal saline $(100: 1 \mathrm{w} / \mathrm{v})$ was sonicated properly, and the supernatant was utilized as a wellspring of basic intestinal $\alpha$-glucosidase after centrifugation. Shortly, $10 \mathrm{~mL}$ of tested samples $(5 \mathrm{mg} / \mathrm{mL})$ in dimethyl sulfoxide solution was reconstructed in $100 \mathrm{~mL}$ of $100 \mathrm{mM}$ phosphate buffer at $\mathrm{pH} 6.8$ out of a 96-well microplate and hatched with $50 \mathrm{~mL}$ of important intestinal $\alpha$-glucosidase for $5 \mathrm{~min}$ before $50 \mathrm{~mL}$ substrate (5 mM, p-nitrophenyl-a-D-glucopyranoside agreed in the 
alike buffer) was included. The p-nitrophenol free was slow at $405 \mathrm{~nm}$ spectrophotometrically (SpectraMax plus384, Molecular Devices Corporation, Sunnyvale, CA, USA) $5 \mathrm{~min}$ after brooding with the substrate. Singular spaces for the test samples were fixed up to exact foundation absorbance where the substrate was altered with $50 \mathrm{~mL}$ of buffer. The control sample controlled $10 \mathrm{~mL}$ DMSO alongside test samples. The percent enzyme inhibition was calculated as

$$
(1-B / A) \times 100
$$

where $A$ was the absorbance of control limited of test samples and $B$ was the absorbance in the presence of test samples.

3.2. Beta Secretase FRET Assay. The crude extracts and isolated daturaolone (1) were assessed for $\beta$-secretase inhibitory potential as per standard procedure [25]. $82.5 \mu \mathrm{L}$ buffer contains $50 \mathrm{mM}$ sodium acetate buffer with $\mathrm{pH} 4.5$ was mixed to each inhibitor, in all wells, and after that, $2.5 \mu \mathrm{L}$ from $20 \mathrm{U} / 100 \mu \mathrm{L}$ solution of the enzyme $(0.5 \mathrm{U})$ should be combined. The reaction mixture was incubated for 20 minutes at $25^{\circ} \mathrm{C}$. Then, the reaction will be starting by combing $62.5 \mathrm{nM}$ from $12500 \mathrm{nM} / 1 \mathrm{~mL}$ solutions of a substrate; the incubation should be again obtained for 60 minutes at $37^{\circ} \mathrm{C}$ in the dark condition. After incubation of a 96-well black plate, $1000 \mathrm{nM}$ from $100 \mu \mathrm{M} / 1 \mathrm{~mL}$ stock solution of extract/fractions and isolated daturaolone (1) were combined; then, the incubation time of the plate should be read by the fluorometer machine (CHAMELEON-HIDEX) as per reported standard procedure [25] . Emissions, as well as excitation for Mca, are 325 and $400 \mathrm{~nm}$, respectively.

\section{Results and Discussion}

Daturaolone (1) was isolated from chloroform fraction and identified as 3-oxo-6 $\beta$-hydroxy- $\beta$-amyrin by different spectroscopic techniques such as ${ }^{1} \mathrm{H}-\mathrm{NMR},{ }^{13} \mathrm{C}-\mathrm{NMR}$, IR, and mass spectral data.

Daturaolone $(\mathbf{1})$ was white crystals; IR $\left(\mathrm{KBr}, \mathrm{cm}^{-1}\right) v_{\max }$ $=1599(\mathrm{C}=\mathrm{C}), 1699(\mathrm{C}=\mathrm{O}), 2918(\mathrm{C}-\mathrm{H}), 3650(\mathrm{OH}) \cdot{ }^{1} \mathrm{H}$ $\mathrm{NMR}\left(500 \mathrm{MHz}, \mathrm{CDCl}_{3}\right): \delta 0.83\left(\mathrm{~s}, 3 \mathrm{H}, \mathrm{CH}_{3}-28\right), 0.85(s$, $\left.6 \mathrm{H}, \mathrm{CH}_{3}-29, \mathrm{CH}_{3}-30\right), 1.08\left(s, 3 \mathrm{H}, \mathrm{CH}_{3}-27\right), 1.15(s, 3 \mathrm{H}$, $\left.\mathrm{CH}_{3}-23\right), 1.22\left(t, 2 \mathrm{H}, \mathrm{CH}_{2}-22\right), 1.32\left(s, 3 \mathrm{H}, \mathrm{CH}_{3}-26\right), 1.40(s$ , $\left.3 \mathrm{H}, \mathrm{CH}_{3}-24\right), 1.49\left(s, 3 \mathrm{H}, \mathrm{CH}_{3}-25\right), 1.53\left(s, 2 \mathrm{H}, \mathrm{CH}_{2}-7\right)$, $1.62\left(t, 2 \mathrm{H}, \mathrm{CH}_{2}-15\right), 1.64(d, 1 \mathrm{H}, \mathrm{CH}-5), 1.65\left(d, 2 \mathrm{H}, \mathrm{CH}_{2^{-}}\right.$ 19), $1.67(t, 1 \mathrm{H}, \mathrm{CH}-18), 1.76\left(m, 2 \mathrm{H}, \mathrm{CH}_{2}-11\right), 1.98(t, 2 \mathrm{H}$, $\left.\mathrm{CH}_{2}-16\right), 2.06(t, 1 \mathrm{H}, \mathrm{CH}-5), 2.22\left(3,2 \mathrm{H}, \mathrm{CH}_{2}-1\right), 2.73$ (3, $\left.2 \mathrm{H}, \mathrm{CH}_{2}-2\right), 4.49$ (brs, $\left.1 \mathrm{H}, \mathrm{CH}-6\right), 5.24\left(s, 1 \mathrm{H}, \mathrm{CH}_{2}-12\right)$; ${ }^{13} \mathrm{C} \mathrm{NMR}\left(125 \mathrm{~Hz}, \mathrm{CDCl}_{3}\right): \delta 16.5\left(\mathrm{CH}_{3}-19\right),\left(\mathrm{CH}_{3}-19\right)$, $18.6\left(\mathrm{CH}_{3}-26\right), 23.6\left(\mathrm{CH}_{3}-11,24\right), 23.9\left(\mathrm{CH}_{3}-30\right), 25.8$ $\left(\mathrm{CH}_{3}-23\right), 25.9\left(\mathrm{CH}_{3}-27\right), 26.1\left(\mathrm{CH}_{2}-15\right), 26.9\left(\mathrm{CH}_{2}-16\right)$, $28.3\left(\mathrm{CH}_{3}-28\right), 31.0(\mathrm{C}-20), 32.8(\mathrm{C}-17), 33.3\left(\mathrm{CH}_{3}-29\right)$, $34.0\left(\mathrm{CH}_{2}-21\right), 34.4\left(\mathrm{CH}_{2}-2\right), 36.3(\mathrm{C}-10), 37.0\left(\mathrm{CH}_{2}-22\right)$, 39.0 (C-14), $40.6\left(\mathrm{CH}_{2}-1\right), 41.6\left(\mathrm{CH}_{2}-7\right), 42.5(\mathrm{C}-8), 46.7$ $\left(\mathrm{CH}_{2}-19\right), 47.3$ (CH-9, 18), 48.7 (C-4), 56.5 (CH-5), 69.3 (CH-6), 121.2 (CH-12), 144.5 (C-13), 216.6 (C-3), ppm; HRMS (ESI) $m / z$ : calcd. for $\mathrm{C}_{30} \mathrm{H}_{48} \mathrm{O}_{2}[\mathrm{M}]^{+440.3710}$ found 440.3700. The spectroscopic data were compared to the
TABLE 1: $\alpha$-Glucosidase inhibitory activity of extract/fractions and isolated daturaolone (1).

\begin{tabular}{lccc}
\hline Sample/standard & Concentration & \% inhibition & $\mathrm{IC}_{50} \pm \operatorname{SEM}(\mu \mathrm{M})$ \\
\hline Hexane & $0.2 \mu \mathrm{g}$ & 42.6 & $\mathrm{NA}$ \\
Chloroform & $0.2 \mu \mathrm{g}$ & 90.8 & $160.2 \pm 1.85$ \\
Ethyl acetate & $0.2 \mu \mathrm{g}$ & 82.7 & $86.2 \pm 2.00$ \\
Methanol & $0.2 \mu \mathrm{g}$ & 80.2 & $110.6 \pm 2.66$ \\
Daturaolone (1) & $0.2 \mu \mathrm{M}$ & 98.7 & $830.4 \pm 2.01$ \\
Standard & $0.2 \mu \mathrm{M}$ & 90.2 & $840.4 \pm 1.74$ \\
\hline
\end{tabular}

$\mathrm{IC}_{50}$ : minimum inhibitory concentration; SEM: standard error of mean; $\mu \mathrm{M}$ : micromolar; Standard: acarbose.

literature and found identical with literature reported data $[21,22]$; furthermore, the chemical structure of daturaolone (1) was confirmed by X-ray crystallography data (Figure 1).

The crude methanolic extract and various fractions and also daturaolone (1) were screened for $\alpha$-glucosidase inhibitory activity; the tested extracts, fraction, and isolated daturaolone (1) were found active on $\alpha$-glucosidase.

Diabetes mellitus is a dominant disease in developed as well as developing countries; it is a prominent metabolic turmoil or in other words an abnormal postprandial increment of blood glucose level. The controller of postprandial hyperglycemia is accepted to be imperative in the cure of diabetes mellitus. $\alpha$-Glucosidase produced from the intestinal chorionic epithelium is responsible for the degradation of the glucose molecules. The inhibitors of $\alpha$-glucosidase (EC 3.2.1.20) are potent antidiabetic agents. Several $\alpha$-glucosidase inhibitors including voglibose and acarbose obtained from a natural source can sufficiently control blood glucose levels and have been used clinically in the cure of diabetes mellitus. Among several natural products, only a few $\alpha$-glucosidase inhibitors are industrially available [22-24].

The obtained results indicated that chloroform fraction exhibited maximum inhibitory potential $90.8 \%$ with $\mathrm{IC}_{50}$ value $160.2 \pm 1.85 \mu \mathrm{M}$ followed by ethyl acetate fraction $82.7 \%$ with $\mathrm{IC}_{50}$ of $86.2 \pm 2.00$. The methanolic extract also showed promising activity with $\%$ inhibition of $80.2 \%$ with $\mathrm{IC}_{50}$ value $110.6 \pm 2.66 \mu \mathrm{g}$, respectively. The daturaolone isolated from most active frication showed potent activity $98.7 \%$ with $\mathrm{IC}_{50}$ value $830.4 \pm 2.01 \mu \mathrm{M}$ as compared to the standard drug having $90.2 \%$ inhibition with $\mathrm{IC}_{50}$ value $840.4 \pm 1.74$ $\mu \mathrm{M}$ (Table 1). The bioactivity of the chloroform extract are correlated due to the presence of daturaolone.

$\beta$-Secretase processing of amyloid precursor protein $(\beta$ APP) is the $1^{\text {st }}$ step in a pathway leading to the formation of $\mathrm{A} \beta$ (amyloid); therefore, it is a major target for the development of a drug for the cure of Alzheimer's disease (AD). The $\beta$-secretase enzyme (BACE1) is important for the production of ab. It has been documented that BACE1 level is high in Alzheimer's disease (AD); therefore, the study BACE1 inhibition is helpful in developing new Alzheimer's disease (AD) therapies [25]. Keeping the significance of BACE1 activity in mind, the crude methanolic extract and various fractions and daturaolone (1) were screened $\beta$-secretase inhibitory potency. Among tested fractions, the 
TABLE 2: $\beta$-Secretase inhibitory activity of extract/fractions and isolated daturaolone (1).

\begin{tabular}{lccc}
\hline Sample/standard & Concentration & \% inhibition & $\mathrm{IC}_{50} \pm \operatorname{SEM}(\mu \mathrm{M})$ \\
\hline Hexane & $0.2 \mu \mathrm{g}$ & 38.28 & $\mathrm{NA}$ \\
Chloroform & $0.2 \mu \mathrm{g}$ & 88.27 & $304.21 \pm 2.98$ \\
Ethyl acetate & $0.2 \mu \mathrm{g}$ & 67.98 & $87.93 \pm 2.87$ \\
Methanol & $0.2 \mu \mathrm{g}$ & 78.42 & $246.51 \pm 1.98$ \\
Daturaolone (1) & $0.2 \mu \mathrm{M}$ & 95.19 & $260.70 \pm 1.87$ \\
Standard & $0.2 \mu \mathrm{M}$ & 94.21 & $289.24 \pm 1.60$ \\
\hline
\end{tabular}

$\mathrm{IC}_{50}$ : minimum inhibitory concentration; SEM: standard error of mean; $\mu \mathrm{M}$ : micromolar; Standard: (Ans670, Sta671, Val672)-amyloid- $\beta / \mathrm{A} 4$ precursor protein 770 fragments 662-675).

chloroform fractions showed excellent activity against $\beta$ secretes (BACE1) enzyme with \% inhibition $88.27 \%$ with $\mathrm{IC}_{50}$ value of $304.21 \pm 2.98 \mu \mathrm{g}$ followed by methanolic extract $78.42 \%$ with $\mathrm{IC}_{50} 246.51 \pm 1.98 \mu \mathrm{g}$, respectively. The ethyl acetate fractions also showed good inhibition with $67.98 \%$ activity with $\mathrm{IC}_{50}$ value $87.93 \pm 2.87 \mu \mathrm{M}$, while $n$-hexane fraction was found the least active (Table 2). The daturaolone (1) was found significantly active against BACE1 enzyme with \% inhibition 95.19 and $\mathrm{IC}_{50}$ value $260.70 \pm 1.87 \mu \mathrm{M}$ as compared to standard having \% activity 94.21 and $\mathrm{IC}_{50}$ value $289.24 \pm 1.60 \mu \mathrm{M}$.

The bioactivity of daturaolone (1) toward $\alpha$-glucosidase and $\beta$-secretase suggests that the bioactivity is due to the keto moiety at position C-3 and a hydroxyl group at position C-6 which may bind with residues in the active sites of selected enzymes.

\section{Conclusion}

Phytochemicals can provide an excellent pharmacophore template for novel drug discovery used for the cure of various diseases. The crude extract/fraction and daturaolone (1) exhibited excellently $\alpha$-glucosidase inhibition activity. Similarly, the extract/fractions and isolated daturaolone (1) showed potent and $\beta$-secretase activity. In this study, the extracts and natural daturaolone (1) inhibit $\alpha$-glucosidase and $\beta$-secretase significantly and can be used as an excellent template compound for the new drug used in diabetes and AD.

\section{Data Availability}

The data such as spectra and the associated analysis used to support the investigation of this study are available from corresponding authors upon request.

\section{Conflicts of Interest}

The authors declare no potential conflict of interest.

\section{Authors' Contributions}

Saud Bawazeer supervised the whole project. Abdur Rauf and Sami Bawazeer performed the experimental part. All authors were involved in editing and gave the final shape to this research. Dr. Saud Bawazeer read the paper and approved it for submission.

\section{Acknowledgments}

The work was funded by grant number 14-MED333-10 from the National Science, Technology and Innovation Plan (MAARIFAH), the King Abdul-Aziz City for Science and Technology (KACST), Kingdom of Saudi Arabia. We thank the Science and Technology Unit at Umm Al-Qura University for their continued logistic support.

\section{Supplementary Materials}

Figure 1: ${ }^{1} \mathrm{H}-\mathrm{NMR}$ NMR spectra of daturaolone (1) isolated from Datura metel. Figure $2:{ }^{13} \mathrm{C}$-HNMR spectra of daturaolone (1) isolated from Datura metel. Figure 3: 2D H-NMR spectra of daturaolone (1) isolated from Datura metel. Figure 4: EI-MS spectra of daturaolone (1) isolated from Datura metel. Figure 5: FT-IR spectra of daturaolone (1) isolated from Datura metel. (Supplementary Materials)

\section{References}

[1] W. Vent, "Duke, J. A. \& Ayensu, E. S., Medicinal Plants of China. 2 Vols. 705 S., 1300 Strichzeichnungen. Reference Publ., Inc. Algonac. Michigan, 1985. ISBN 0-917266-20-4. Preis: geb. m. Schutzumschlag \$94,95," Feddes Repertorium, vol. 98, no. 7-8, p. 398, 1987.

[2] R. Dabur, M. Ali, H. Singh, J. Gupta, and G. L. Sharma, "A novel antifungal pyrrole derivative from Datura metel leaves," Pharmazie, vol. 59, no. 7, pp. 568-570, 2004.

[3] R. Vassar, D. M. Kovacs, R. Yan, and P. C. Wong, "The -Secretase Enzyme BACE in health and Alzheimer's disease: regulation, cell biology, function, and therapeutic potential," The Journal of Neuroscience, vol. 29, no. 41, pp. 12787-12794, 2009.

[4] D. E. Okwu and E. C. Igara, "Isolation, characterization and antibacterial activity of alkaloid from Datura metel Linn leaves," African Journal of Pharmacy and Pharmacology, vol. 3, no. 5, pp. 277-281, 2009.

[5] R. N. Chopra, S. N. Nayar, and I. C. Chopra, Glossary of Indian Medicinal Plants, vol. 91, Council of Scientific and Industrial Research, New Delhi, India, 1956.

[6] R. N. Chopra, S. L. Nayar, and L. C. Chopra, Glossary of Indian Medicinal Plants, Council of Scientific and Industrial Research, New Delhi, India, 1986.

[7] B. Y. Yang, R. Guo, T. Li et al., "New anti-inflammatory withanolides from the leaves of Datura metel L," Steroids, vol. 87, pp. 26-34, 2014.

[8] M. Abubakar, U. Suleiman, A. Frank, and A. Ukwuani, "Hallucinogenic effects of aqueous seeds extract of Datura metel in rats," Internet Journal of Pharmacology, vol. 9, no. 1, pp. 8389, 2009.

[9] T. N. Arjun, H. Sudhir, E. Saxena, A. Dayma, R. S. Raghuvanshi, and R. Shah, "Role of siddha system of medicine in the management of oro-facial diseases," World Journal of Pharmaceutical Sciences, vol. 4, no. 8, pp. 1661-1671, 2015.

[10] P. Soni, A. A. Siddiqui, J. Dwivedi, and V. Soni, "Pharmacological properties of Datura stramonium L. as a potential 
medicinal tree: an overview," Asian Pacific Journal of Tropical Biomedicine, vol. 2, no. 12, pp. 1002-1008, 2012.

[11] T. H. A. Alabri, A. H. S. Al Musalami, M. A. Hossain, A. M. Weli, and Q. Al-Riyami, "Comparative study of phytochemical screening, antioxidant and antimicrobial capacities of fresh and dry leaves crude plant extracts of Datura metel L," Journal of King Saud University - Science, vol. 26, no. 3, pp. 237-243, 2014.

[12] F. C. Akharaiyi, "Antibacterial, phytochemical and antioxidant activities of Datura metel," International Journal of PharmTech Research, vol. 3, no. 1, pp. 478-483, 2011.

[13] G. V. Satyavati and M. K. Raina, Medicinal Plants of India, vol. 1, Indian Council for Medical Research Publication, New Delhi, India, 1977.

[14] S. T. Assefa, E. Y. Yang, S. Y. Chae et al., "Alpha glucosidase inhibitory activities of plants with focus on common vegetables," Plants, vol. 9, no. 1, p. 2, 2020.

[15] G. J. Davies, T. M. Gloster, and B. Henrissat, "Recent structural insights into the expanding world of carbohydrate-active enzymes," Current Opinion in Structural Biology, vol. 15, no. 6, pp. 637-645, 2005.

[16] D. J. Vocadlo and G. J. Davies, "Mechanistic insights into glycosidase chemistry," Current Opinion in Structural Biology, vol. 12, no. 5, pp. 539-555.

[17] T. Kajimoto and M. Node, "Inhibitors against glycosidases as medicines," Current Topics in Medicinal Chemistry, vol. 9, no. 1, pp. 13-33, 2009.

[18] H. Wang, R. Li, and Y. Shen, " $\beta$-Secretase: its biology as a therapeutic target in diseases," Trends in Pharmacological Sciences, vol. 34, no. 4, pp. 215-225, 2013.

[19] A. E. Stutz and T. M. Wrodnigg, "Imino sugars and glycosyl hydrolases," Advances in Carbohydrate Chemistry and Biochemistry, vol. 66, pp. 187-298, 2011.

[20] S. Bawazeer, A. Rauf, S. U. A. Shah et al., "Antioxidant and enzyme inhibitory activities of extracts and phytochemicals isolated from Pistacia integerrima," Journal of Medicinal and Spice Plants, vol. 23, no. 2, pp. 55-58, 2019.

[21] K. Wang, H. Sun, B. Wu, and Y. Pan, "Two novel olean triterpenoids from Celastrus hypoleucus," Helvetica Chimica Acta, vol. 88, no. 5, pp. 990-995, 2005.

[22] Y. W. Mak, L. O. Chuah, R. Ahmad, and R. Bhat, "Antioxidant and antibacterial activities of hibiscus (Hibiscus rosa-sinensis L.) and Cassia (Senna bicapsularis L.) flower extracts," Journal of King Saud University - Science, vol. 25, no. 4, pp. 275-282, 2013.

[23] Z. Yin, W. Zhang, F. Feng, Y. Zhang, and W. Kang, " $\alpha$-Glucosidase inhibitors isolated from medicinal plants," Food Science and Human Wellness, vol. 3, no. 3-4, pp. 136-174, 2014.

[24] G. Uddin, A. Rauf, A. M. Al-Othman et al., "Pistagremic acid, a glucosidase inhibitor from Pistacia integerrima," Fitoterapia, vol. 83, no. 8, pp. 1648-1652, 2012.

[25] A. Rauf, G. Uddin, A. Khan et al., "Pistagremic acid, a novel $\beta$ secretase enzyme (BACE1) inhibitor from Pistacia integerrima Stewart," Natural Product Research, vol. 29, no. 18, pp. 17351738, 2015. 